\title{
Development of STEM-Based Physics Teaching Materials Integrated 21st Century Skills (4C) and Characters
}

\author{
Rachmat Waluyo ${ }^{(*)}$, Siti Wahyuni \\ Universitas Negeri Semarang
}

\begin{abstract}
Received: November 17, 2020 Teaching materials currently available are mostly centered on textbook Revised: December 23, 2020 and tasks. Moreover, it is rarely implanted with 21 st century skills and Accepted: January 04, 2021 character values so that students find it difficult when solving problems related to life. STEM-based teaching materials developed are presented with characteristics of fluid information which is complemented by discussions, practicum, and project activities related to STEM aspects and integrated with 21 st century skills (4C) and character values so that students are encouraged to be more active in solving problems. This study aims to describe characteristics and identify feasibility, readability, student responses to STEM-based physics teaching materials, integrated 21st century skills (4C), and characters. The method used in this research was Research and Development (R\&D) with producers adapted from the research and development steps of Borg and Gall, which are modified into seven stages. Data collection techniques in this study were carried out in several ways, namely interviews, tests, and questionnaires placed on a Likert scale. The results of the feasibility test showed that the teaching materials were in a very worthy category. The readability test results showed that the teaching materials were presenting in the class easily understood. The assessment of students' responses to teaching materials showed an excellent category to be used by the second-year student at high school as a supporting learning source in the fluid subject learning process.
\end{abstract}

Keywords: teaching material, STEM, 21 st century skills, character.

(*) Corresponding Author: $\quad$ rachmatwaluyo764@gmail.com

How to Cite: Waluyo, R. \& Wahyuni, S. (2021). Development of STEM-based physics teaching materials integrated 21st century skills (4C) and characters. Formatif: Jurnal Ilmiah Pendidikan MIPA, 11 (1): 83102. http://dx.doi.org/10.30998/formatif.v11i1.7951

\section{INTRODUCTION}

Education is an essential asset for a nation's sustainability and progress, especially to prepare a generation that can compete in the 21 st century. Science and technology which are increasingly developing demands that students have abilities that are in accordance with the times. The $4 \mathrm{C}$ skills in the 21 st century are critical thinking skills, creativity, communication, and collaboration. The government continuously made an effort to improve the quality of education in Indonesia. One of them is through changes to the national education curriculum, starting from the 1947 Lesson Plan Curriculum to the revised 2013 Curriculum used to date. The main focus of the 2013 Curriculum is the activeness of students, the integration of 21 st century skills, and character education in learning. Through the currently implemented 2013 Curriculum, the expected competence after studying physics at the high school level is to live a life with a positive attitude with critical, creative, innovative, and collaborative thinking, along with honesty and openness based on the potential of the product process and understanding the impact of developments in technology (Kemendikbud, 2016). 
One of the government's efforts to improve the quality of education in Indonesia, according to Bappenas (2013), is through the development of teaching materials to support the learning process. The research is in line with the research results by Ariyani \& Wangid (2016), which states that innovative teaching materials developed can instill certain characters embedded in students. According to Widayoko et al. (2018), to face the times' demands, teaching materials are needed that can help students understand the material. Also, its application in technology can raise students' curiosity in engineering technology with the concepts being studied. As a result, students master scientific literacy competencies and have broad insights. Learning with the STEM approach integrates science, technology, engineering, and mathematics learning to help 21 st century skills by focusing on solving real problems related to everyday life. The use of the STEM approach to learning could be applied in models, teaching materials, and LKPD as well as improving students' problem-solving skills (Chien \& Lajium, 2016; Fitriani et al., 2017). The results of Yildırım \& Altun's (2015) research shows that the STEM approach can lead to effective and quality learning, relates to everyday life experiences, and develops problem solving skills such as creativity and critical thinking.

In reliance on the suitability between the learning objectives with the STEM approach and the learning objectives in secondary schools listed in the 2013 Curriculum, it can be concluded that the 2013 Curriculum learning provides opportunities for the development and implementation of STEM. It can also develop students' critical thinking skills, creativity, innovation, and problem-solving and development skills of the students' character. In this case, it means that the teaching materials are oriented to the material and practice questions. Teaching materials should be oriented towards environmental problems and application of technology using the STEM approach and prioritizing multi and transdisciplinary integration of S, T, E, and $\mathrm{M}$ and the development of $4 \mathrm{C}$ and character development of students.

Regarding the results of observations in the works of monitoring at SMA Negeri 1 Patikraja, it was found that the learning resources of students were in the form of textbooks and student worksheets, which indicated that these learning resources were still centered on cognitive aspects without an emphasis on affective and applicable aspects that encouraged mastery of 21 st century skills and character education. The above problems provide an overview of the urgency of the need for learning resources that support learning physics to improve 21 st century skills and students' character. Therefore, research is needed on the development of STEM-based teaching materials integrated 21st century skills and the character of students in high school physics learning. The purpose of this study was to describe the characteristics, feasibility level, readability level, and students' responses to the teaching materials developed.

\section{METHODS}

The method used in this research was Research and Development (R\&D). This research was conducted in January - May 2020 at SMA Negeri 1 Patikraja, located at Jalan Adipura No. 3, Patikraja District, Banyumas Regency, Central Java Province. The subjects in this study were lecturers of material experts and media experts, physics teachers of SMA Negeri 1 Patikraja, and students of class XI MIPA 3 and XI MIPA 5 SMA Negeri 1 Patikraja.

The data collected in this research used interview methods, questionnaires, and tests. Interviews were conducted at the information gathering stage of the physics teacher and some students of SMA Negeri 1 Patikraja to obtain data about physics teaching materials used by students at the school and to find out directly the students' responses to 
the teaching materials. The research instruments used were the gaps test and questionnaire. The gap test was used to determine the teaching material's readability. Then it was tested for its validity using the validator's expert judgment techniques. The reliability test for the intercept test instrument was not carried out.

The feasibility level, readability level, and student responses are expressed as the percentage score $(\mathrm{P})$ and calculated by looking for the percentage of the score obtained compared to the maximum score. Data brought conclusions about students' feasibility, legibility, and responses to teaching materials linked to the Likert scale from the data analysis results.

The procedure used in this study was adapted from the research and development steps by Borg \& Gall (1989), as shown in Figure 1.

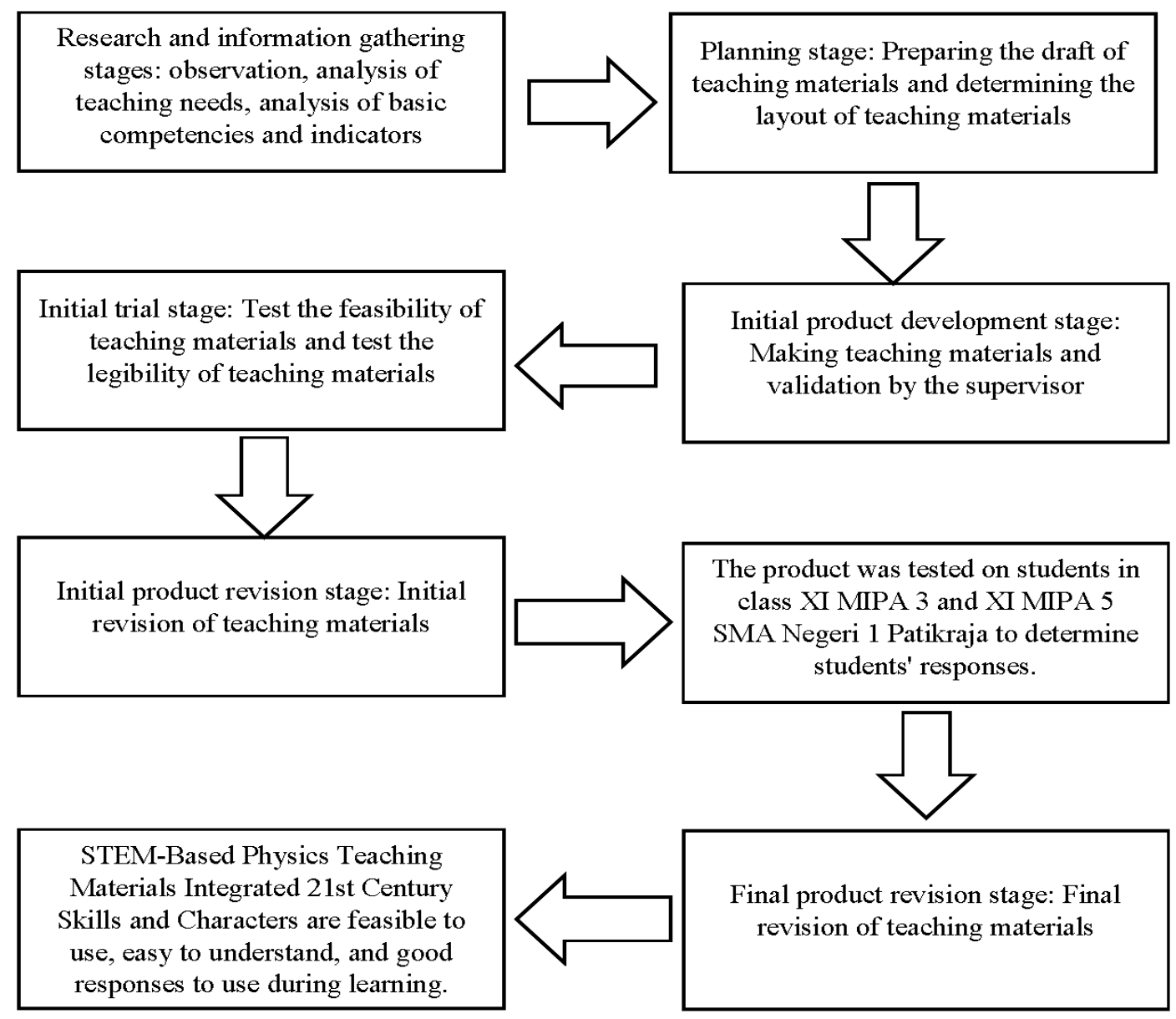

Figure 1. The research procedure used

\section{RESULTS \& DISCUSSION}

\section{Characteristics of Teaching Materials}

This research's product was in the form of STEM-based physics teaching materials integrated with 21 st century skills $(4 \mathrm{C})$ and character. The teaching material contained fluid material related to science, technology, engineering, and mathematics and, in its presentation, also integrates 21 st century skills (4C) and character education. Teaching 
materials were made from Microsoft Word 2016 software to compile the material and assisted with CorelDraw X7 software for making graphic designs of teaching materials. The text in the teaching material was written in Times New Roman font and font size of 12-16. The use of writing teaching materials above aimed to make teaching materials visible and easy to read. The statement was in line with Nurhadryani et al.'s (2013) research results, which stated that the appropriate type and size of letters would make it easier for students to learn the material in teaching materials. Also, on each side of the teaching material, pictures were given following the material's discussion. The picture aimed to provide a sense of comfort and make it easier for students to understand the material so that there was no misunderstanding about Situmorang (2014) research, which stated that suitable teaching materials present pictures that could motivate learners to support problem-solving activities.

STEM-based physics teaching materials integrated 21 st century skills and character content were divided into three parts: the initial element, the content part, and the final part. The total number of teaching materials is 69 pages and was printed using A4 paper $(21 \mathrm{~cm} \times 29.7 \mathrm{~cm})$. The content was so that the school's learning needed developed physics teaching materials and outside school (Prastowo, 2015).

The initial section consisted of covers, introductions, a brief profile of teaching materials, a table of contents, instructions for using teaching materials, essential competencies and indicators of competency achievement, and a concept map. The content section consisted of two chapters, namely static fluid and dynamic fluid. In each chapter, there was a discussion activity integrated 21 st century skills (4C), which was contained in the content "Come on, observe!" and "Come on, Discuss!". Before explaining the material, the content "Come on, learn!" contained keywords and the importance of studying the material. The descriptions of the material in the developed teaching materials are presented in detail and arranged systematically to make it easier for students to understand the material. Also, there is the content "Come on, Try It!" and "Come on, Project!" which contains experimental activities and project activities (making a prototype of a tool that applies a particular concept) equipped with student worksheets. Contextual elements and STEM linkages appear in the "STEM Rubric" content. "Character Values" contained religious, curiosity, discipline, and social care character. Other contents used were "Our Figures", which contains historical figures who contributed to discovering physics concepts. Also, "Sample Questions", which included examples of questions from the material that has been presented. This teaching material also included the "Competency Test", which contained items to determine students' ability regarding fluid material included in this developed physics teaching material. The format for arranging the content of teaching materials developed was also made consistently from beginning to end. In line with Arsyad's (2014) statement, print-based media must pay attention to the consistency of the format in which it was prepared.

The teaching materials developed have the characteristics of STEM-based learning. The integration of each aspect of STEM in the teaching materials developed can be explained as follows.

a. The scientific aspect is the central aspect of the teaching materials developed. This was because the subject of physics is one of the main domains in science. Each chapter presented scientific aspects, especially on static and dynamic fluids, such as Pascal's law, Archimedes law, continuity law, Bernoulli's law, and other subsections in a fluid material.

b. The technological aspects of the teaching materials developed were applying concepts to fluid material in everyday life such as water pumps, hydraulic jacks, infusions, showers, airplane wings, and other technologies related to liquid materials. This aspect 
was presented in the form of supporting information about the use of technology in a concept.

c. Engineering aspects in the developed teaching materials are integrated into an explanation of the working principles of technology. It also used concepts in a fluid material, simple project activities (making a prototype of a tool that applies a particular concept), and questions about how a design supports a technology to maximize its utilization.

d. Mathematical aspects can be found in almost all parts of the teaching material. This was because definitions, theories, and physical models were always expressed in mathematical relationships. In mathematical information presented mathematical aspects of the developed teaching related to mathematical formulas/symbols/quantities/operations on the fluid material being discussed.

The physics teaching materials developed also have the integrated characteristics of 21 st century skills (4C). The integration of each $4 \mathrm{C}$ skill in the teaching materials developed can be explained as follows.

a. Critical thinking skills (critical thinking) in the developed teaching materials are integrated into the form of STEM-based learning activities. It was also related to problem-solving. As Saputra et al. (2019) stated, critical thinking skills could be developed through learning that actively engages students in discussion activities to solve a problem.

b. Communication skills (communication) in the developed teaching materials are integrated into learning activities related to problem-solving in group activities and presentation of discussion results. Therefore, Choridah (2013) stated that problembased learning involving group activities and presentations could spur students to communicate with friends and teachers.

c. Collaboration skills (collaboration) in the developed teaching materials are integrated into group work activities and discussion results. As Scott (2015) stated, problembased learning and projects involving group activities or work collaboratively could spur students to develop collaborative skills.

d. Creativity skills (creativity / creative thinking) in the developed teaching materials are integrated into the form of STEM-based learning activities related to problem-solving. As the results of their research, Irfana et al. (2019) state that STEM-based learning can improve students' creative thinking skills. The physics teaching materials developed also have the integrated characteristics of 21 st century skills (4C). The integration of each $4 \mathrm{C}$ skill in the teaching materials developed can be explained as follows.

In addition to being integrated 21 st century skills (4C), the teaching materials developed also have characteristics loaded with character values, including religion, curiosity, discipline, and social care. These characters were selected based on an analysis of their needs and the material context (Nurgiyantoro \& Efendi, 2013). Integrating these character values was reflected in the instructions in discussion activities, practicum, and projects in teaching materials. This was in line with Khusniati's (2012) results, which stated that independently discovering concepts such as practicum activities could foster students' various kinds of characters. Also, to further maximize character cultivation in the developed teaching materials, there was "Character Values" content containing instructions or information about the relationship between the material and the fourcharacter values developed to motivate students to increase their character values further. The content of "Character Values" was presented in a separate box column. Based on Arsyad's opinion (2014), emphasis using boxes could be used to mark important information in teaching materials. Based on the results of Pala's (2011) research, character planting in students could be useful if it was done repeatedly and continuously. Thus, in the learning process, the teacher could instill character values continually. 
Some examples of the results of product development for teaching materials in the content section are presented in the image below.

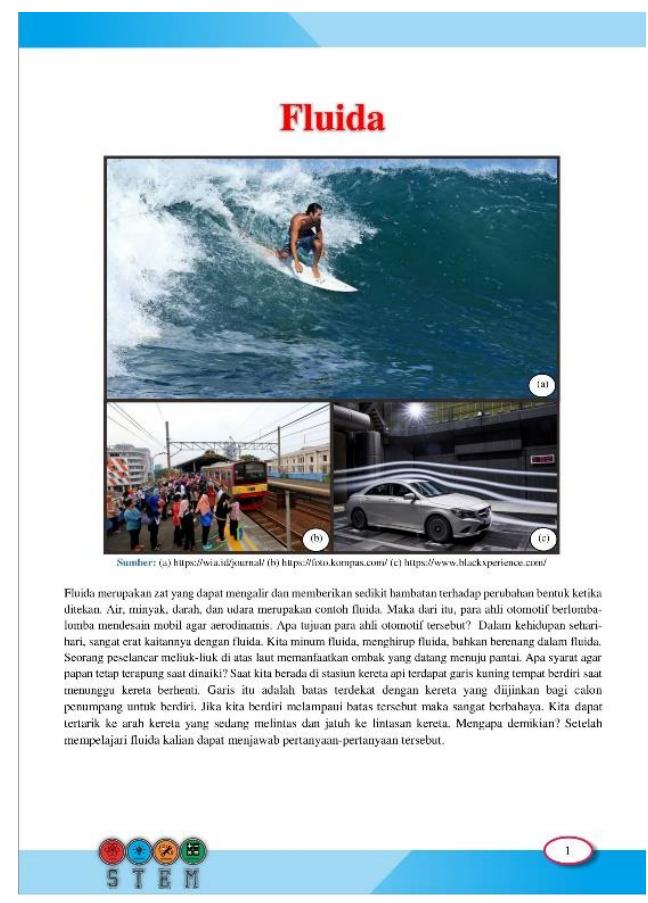

Figure 2. Introduction to teaching materials

\section{A. Fluida Statis}

Pembahasan fluida dimulai dengan fluida statis atau fluida diam. Untuk menyederhanakan pembahasan dalam bab ini, fluida yang akan dibahas yaitu fluida ideal. Mengapa demikian?

\section{Ayo, Belajar!}

PokokBahasan : Fluida statis.

Kata Kunci : Fluida statis, tekanan fluida, hukum Pascal, hukum Archimedes, tegangan permukaan, meniskus dan kapilaritas, viskositas dan hukum Stokes.

Mengapa Penting?

Setelah kita mempelajari materi fluida statis, kita dapat memahami konsep tentang fluida statis dan aplikasinya dalam kehidupan sehari-hari.

Figure 3. The content section "Come on, Learn!" on teaching materials 


\section{Hukum Archimedes}

Pada sub bab sebelumnya kalian telah mempelajari mengenai tekanan hidrostatis dan pemanfaatannya. Pada sub bab ini, kalian akan mempelajari hukum Archimedes. Sebelum mempelajari lebih lanjut tentang hukum Archimedes, mari lakukan kegiatan berikut.

\section{Ayo, Mengamati!}

Perhatikan gambar kapal selam pada Gambar 18 !

Salah satu teknologi canggih yang memanfaatkan prinsip mengapung, melayang, dan tenggelam adalah teknologi kapal selam. Kapal selam memiliki ruang khusus penampung air. Jumlah air yang ditampung dapat ditambah dan dikurangi.

Jawablah pertanyaan-pertanyaan berikut ini!

1. Bagaimana cara kerja kapal selam tersebut?

2. Berikan tanggapan kalian terhadap desain kapal selam tersebut!

3. Analisis faktor-faktor apa saja yang menyebabkan kapal selam mampu mengapung, melayang, dan tenggelam!

4. Setelah kalian menjawab pertanyaan di atas, buatlah kesimpulan sesuai dengan jawaban kalian!

Figure 4. The content section "Come on, Observe!" on teaching materials

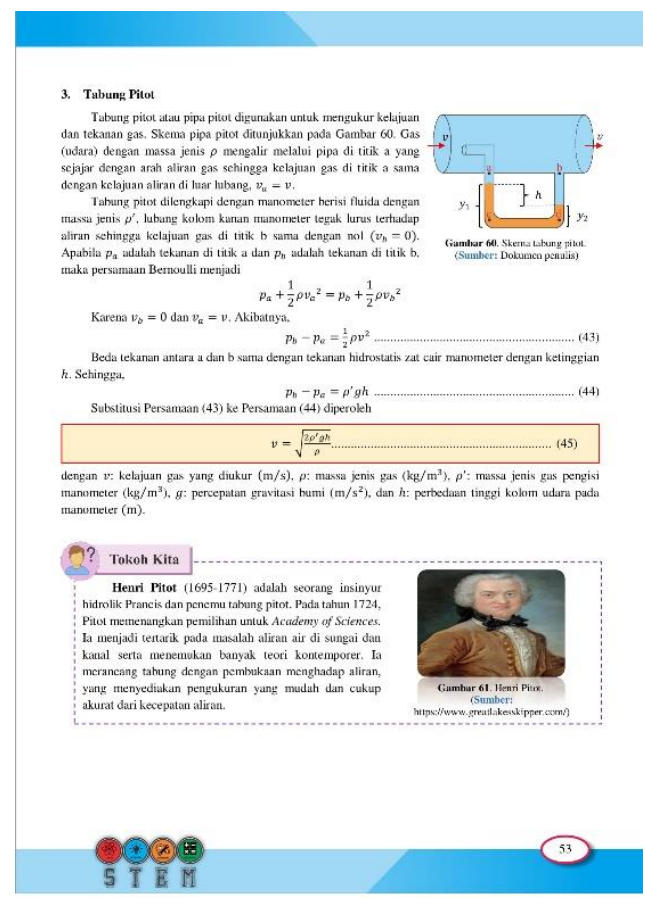

Figure 5. Section description of teaching materials 


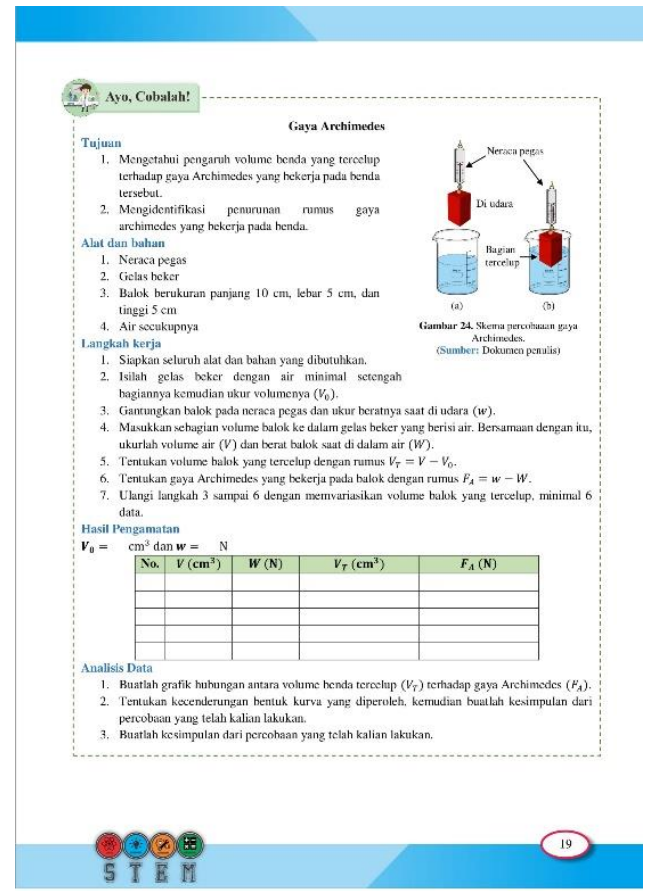

Figure 6. The content section "Come on, Try It!" on teaching materials

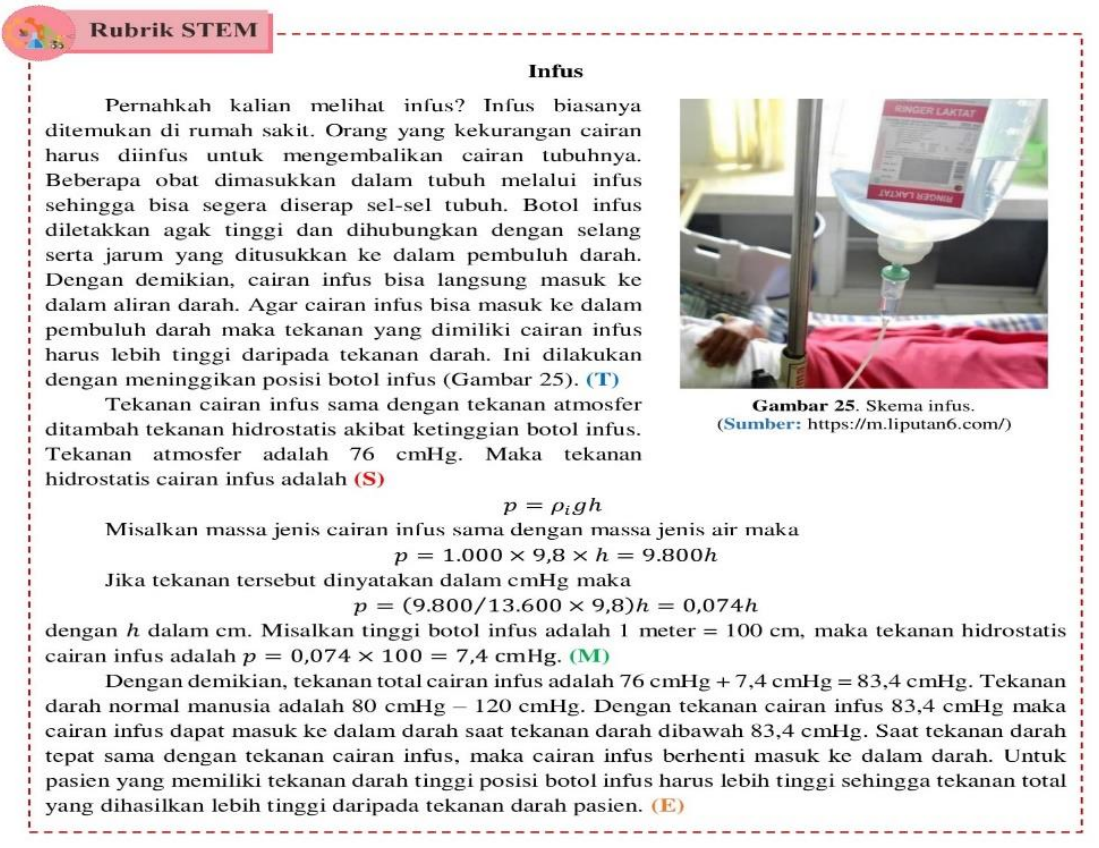

Figure 7. Content section "STEM Rubric" on teaching materials 


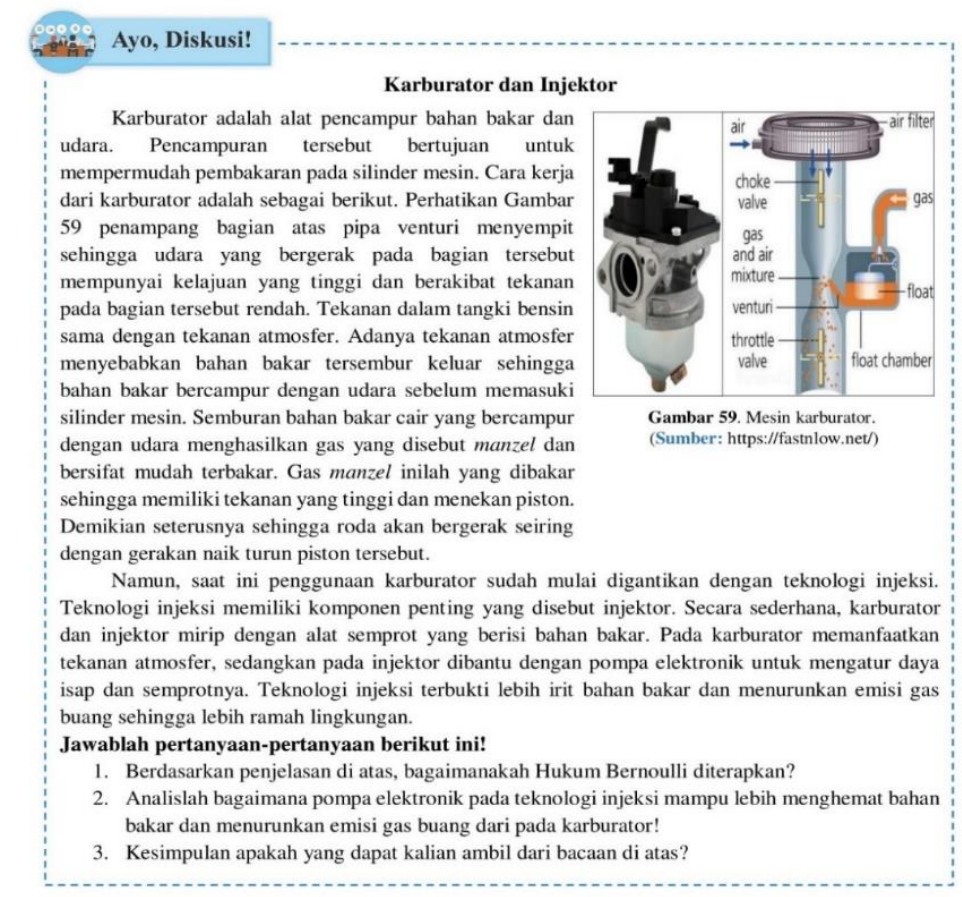

Figure 8. The content section "Come on, Discussion!" on teaching materials

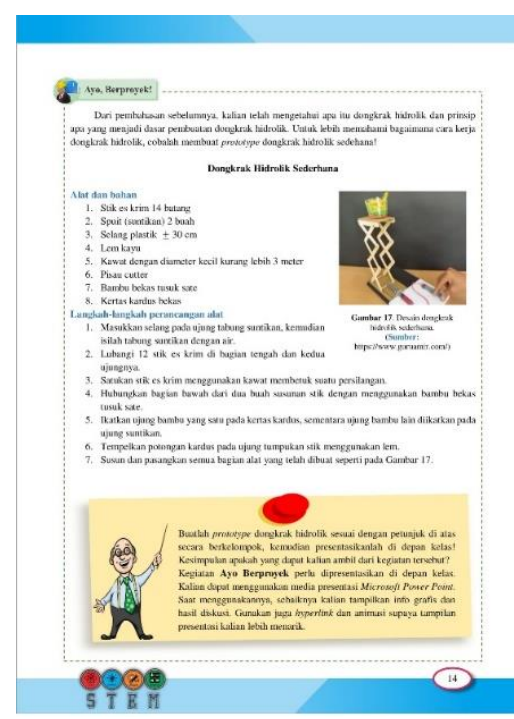

Figure 9. The content section "Come on, Project!" on teaching materials

\section{Nilai Karakter}

\section{Disiplin}

Sahabat, lakukanlah kegiatan proyek ini dengan penuh ketekunan dan kedisiplinan! Dengan mengikuti prosedur proyek ini, kalian akan mendapat pemahaman yang lebih dalam mengenai materi ini jika kalian bersungguh-sungguh.

Figure 10. The content section "Character Values" in teaching materials 


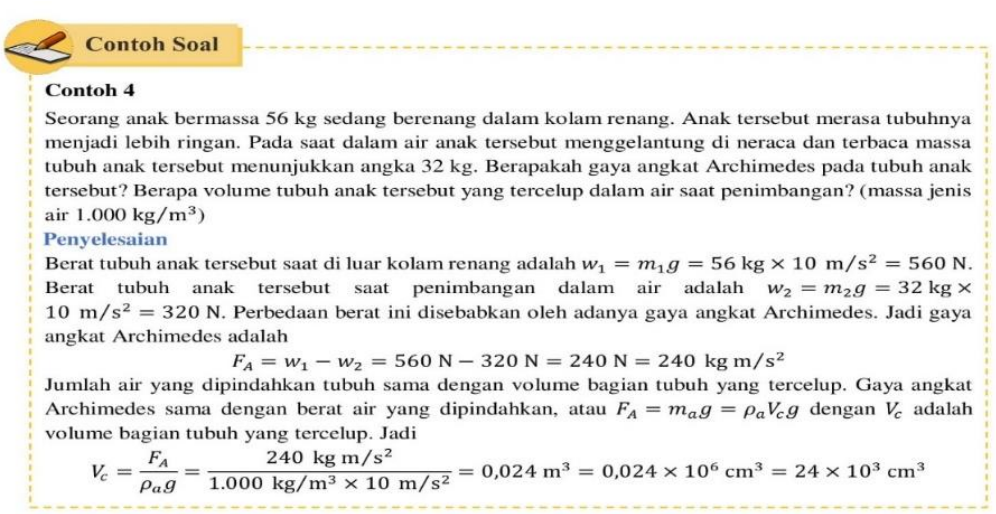

Figure 11. The content section "Sample Questions" on teaching materials

\section{Tokoh Kita}

Prof. Dr. Ing. H. Bacharuddin Jusuf Habibie, FREng. (1936-2019) adalah Presiden Republik Indonesia yang ketiga. Dimasa kecil Habibie telah menunjukkan kecerdasan dan semangat tinggi pada ilmu pengetahuan dan teknologi khususnya fisika. Hingga memasuki usia 40 tahun, karir Habibie sudah sangat cemerlang, terutama dalam desain dan konstruksi pesawat terbang. Beberapa rumusan teorinya dikenal dalam dunia pesawat terbang seperti "Habibie Factor", "Habibie Theorem", dan "Habibie Method". Pada tahun 1976, Lembaga Industri Pesawat Terbang Nurtanio (LIPNUR) yang dipimpin Nurtiano dan kawan-kawan berubah nama menjadi Industri

Pesawat Terbang Nurtanio (IPTN) yang dipimpin oleh Habibie.

Sejak kepemimpinannya, Habibie mengembangkan sejumlah teknologi dan kerja sama dengan negara lain dalam membuat sejumlah pesawat terbang, seperti CN235 (diproduksi massal tahun 1983), N250, dan N2130. Industri pesawat terbang yang pertama dan satu-satunya di Asia Tenggara ini kemudian berganti nama menjadi Industri Pesawat Terbang Nusantara (IPTN) pada 11 Oktober 1985.

Figure 12. The content section "Our Figures" in teaching materials
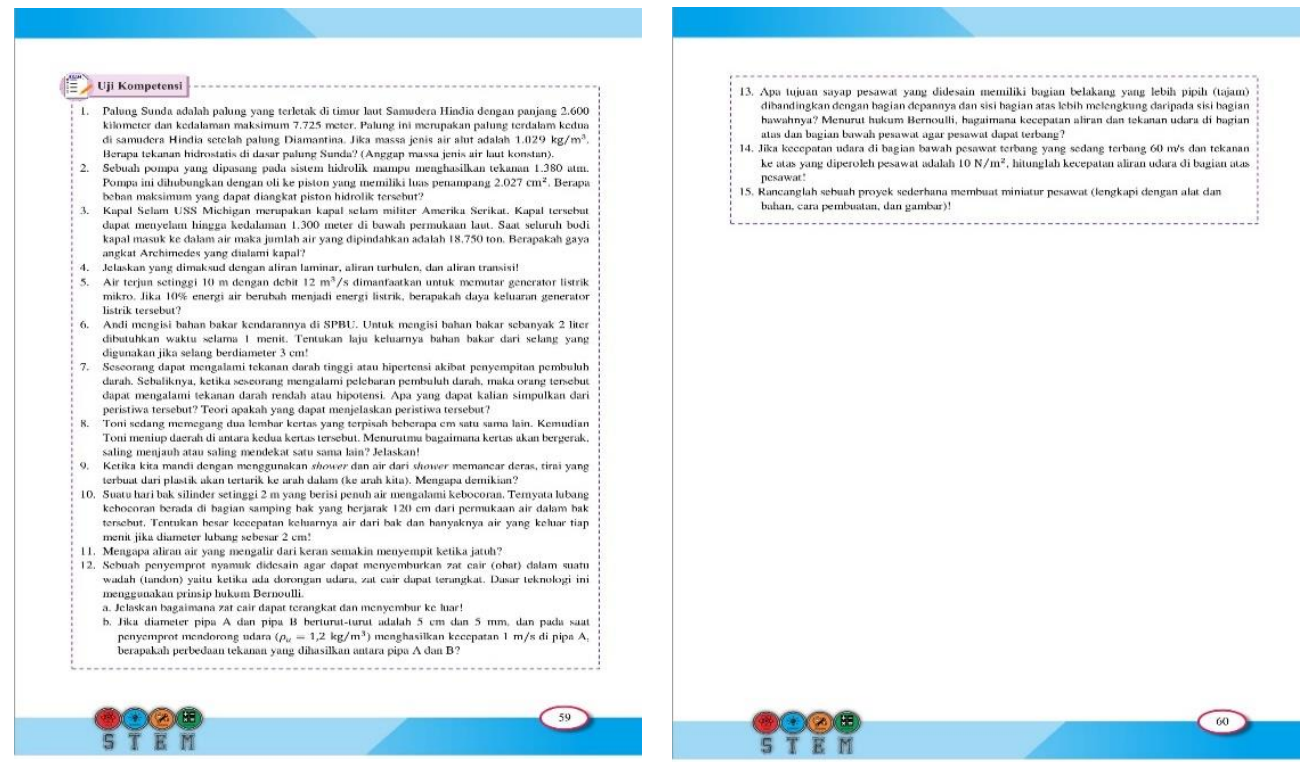

Figure 13. The content section "Competency Test" on teaching materials 
The final part of the teaching materials developed consisted of a summary glossary and bibliography. The summary contained a summary of the material that has been studied in the teaching materials to make it easier for students to review the material. This was in line with the opinion of Daryanto \& Dwicahyono (2014), which states that the summary in teaching materials was prepared by examining the main things contained in the teaching material. The glossary contains explanations of newly introduced terms in teaching materials arranged alphabetically (Daryanto \& Dwicahyono, 2014). The bibliography included a list of reference sources for the material used in teaching materials.

\section{The Feasibility of Teaching Materials}

The feasibility test was carried out by giving a feasibility questionnaire to 3 validators consisting of one material expert lecturer, one media expert lecturer, and one physics teacher. The eligibility questionnaire referred to the test instrument that has been made based on the modified BSNP rules. The feasibility questionnaire consisted of four aspects, namely, content, presentation, language, and geography. The recapitulation of the feasibility test results on each element of the assessment in teaching materials was shown in Table 1.

Table 1. Review of the Results of Feasibility Test for Teaching Materials for Each Aspect

\begin{tabular}{lll}
\hline Eligibility Aspects & $P(\%)$ & Criteria \\
\hline Content & 92,54 & Very worthy \\
Presentation & 93,75 & Very worthy \\
Language & 91,67 & Very worthy \\
Graphic & 87,50 & Very worthy \\
\hline Average & 91,36 & Very worthy \\
\hline
\end{tabular}

The validator's analysis of the feasibility test has met the very worthy criteria with a value percentage of $91.36 \%$. It also meant that STEM-based physics teaching materials integrated 21st century skills $(4 \mathrm{C})$ and character have met the standard of eligibility of printed teaching materials applied by BSNP for learning with some improvements according to validator suggestions. This was in line with Budiawati \& Kantun (2016) opinion, which stated that the feasibility of teaching materials was seen from the teaching materials' ability to meet the feasibility assessment standards set by BSNP.

The teaching material products developed are also compiled based on the preparation guidelines in the 2013 Revised Edition of the Curriculum 2013, a STEM approach, and integrated 21st century skills and character content. This added value of the teaching materials developed compared to the textbooks and LKPD used by students at SMA Negeri 1 Patikraja.

The analysis results on the feasibility aspect of the content of teaching materials, which consisted of six sub aspects, were presented in Table 2.

Table 2. Results of Content Feasibility Aspect Analysis

\begin{tabular}{lll}
\hline Sub aspects & $P(\%)$ & Criteria \\
\hline Material suitability & 94,44 & Very worthy \\
Material accuracy & 91,67 & Very worthy \\
Contemporary material & 100 & Very worthy \\
STEM based & 93,75 & Very worthy \\
21st Century Skills Integration (4C) & 95,83 & Very worthy \\
Integration of character values & 87,50 & Very worthy \\
\hline
\end{tabular}


In reliance on the analysis of the results of the content feasibility aspect test presented in Table 2, it was found that the teaching materials developed got an average percentage of $92.54 \%$ with very worthy criteria in the content feasibility aspect. STEMbased physics teaching materials integrated 21 st century skills, and character content was compiled through the presentation of material that has been adjusted to the Core Competencies (KI), and Basic Competencies (KD) of the 2013 Revised 2017 Curriculum for physics subjects' class XI SMA / MA. This was in line with Prastowo's (2015) opinion which states that the material in teaching materials is very dependent on the basic competencies to be achieved.

The material in the developed teaching materials was also compiled regarding technological developments to facilitate students to construct their knowledge according to the times. As stated by Izzati et al. (2019), utilizing the latest technology currently running in this century can enrich material development. Examples of contextual physics in the teaching materials developed can also help students understand existing concepts easily (Oktaviani et al., 2017). The presentation of STEM-based learning is suitable for physics subjects, develops life skills, creates career awareness, attracts students' attention, and makes learning fun (Kanadli, 2019).

The integration of 21 st century skills (4C) in the developed teaching materials was presented with concrete problems around the latest technology to become more enthusiastic in learning them. STEM-based learning has proven effective in helping students develop 21st century (4C) skills because 4C skills were also skills developed in the STEM curriculum to allow students to choose a future career (Beers, 2011; Sar1 et al., 2018).

Instructions on teaching materials activities were presented by integrating religious character values, curiosity, discipline, and social care. Character education could be delivered through instruction in teaching material activities to improve students' character development (Larasati \& Yulianti, 2014; Wahyuni et al., 2017).

The analysis results on the feasibility aspect of presenting teaching materials, which consisted of three sub aspects, were shown in Table 3.

Table 3. Results of the Analysis of Presentation Feasibility Aspects

\begin{tabular}{lll}
\hline Sub Aspects & $P(\%)$ & Criteria \\
\hline Presentation technique & 100 & Very worthy \\
Learning presentation & 94,44 & Very worthy \\
Presentation completeness & 91,67 & Very worthy \\
\hline
\end{tabular}

Regarding the analysis of the results of the presentation feasibility aspect test presented in Table 3, it was found that in the presentation feasibility aspect, the teaching materials developed got an average percentage of $93.75 \%$ with very worthy criteria.

The material in the developed teaching materials was presented coherently from general/basic concepts to more specific/complex concepts. The developed teaching materials consistently showed a pattern of activity sequences and components of STEMbased learning offerings always presented, making it easier for students to understand them. Teaching materials that were arranged with coherent and consistent concepts could advance students more interested in learning and make it easier for students to understand a concept (Parmin \& Peniati, 2012; Rahmayantis, 2017).

STEM-based physics teaching materials were presented by paying attention to active and interactive student involvement, which was shown through discussion activities, practicums, and projects carried out in groups. Therefore, Pangesti et al. (2017) stated that STEM-based teaching materials that were equipped with discussion activities, practicum, and project creation could improve students' mastery of concepts. STEM- 
based learning can have a positive impact on student learning outcomes in school, such as student interest and motivation, student attitudes towards lessons, improve science process skills, and can help students lead to independent discovery of a concept by students (Herak \& Lamanepa, 2019; Yildirim, 2016). The presentation completeness of the developed teaching materials was divided into three parts: the beginning, the content, and the end, according to Depdiknas (2008).

Table 4 presented the results of the analysis on the linguistic feasibility aspect of teaching materials, which consist of six sub-aspects.

Table 4. Results of the Analysis of Language Feasibility Aspects

\begin{tabular}{lll}
\hline Sub Aspects & $P(\%)$ & Criteria \\
\hline Legibility & 95,83 & Very worthy \\
Conformity with Indonesian language rules & 83,33 & Worthy \\
\hline
\end{tabular}

Table 4 presented the analysis of the test results on the feasibility of the linguistic aspects. In language eligibility, the teaching materials developed got an average percentage of $91.67 \%$ with very worthy criteria. The rate was because the terms, symbols, and icons used in the teaching materials developed were arranged consistently to avoid confusion. According to Purnanto \& Mustadi (2018), consistent use of terms from beginning to end could make it easier for students to understand the book's contents. Also, teaching materials were prepared by paying attention to the structure of the SPO / SPOK in a sentence according to the General Guidelines for Indonesian Spelling (PUEBI) and adjusted to the reader (high school education level students), so that students can easily understand them. As stated by Sorraya (2014), teaching materials developed according to the level of cognitive development of students could make it easier for students to understand every activity in the teaching material.

Table 5. presented the analysis results on the feasibility of the graphic aspects of teaching materials, which consisted of three sub-aspects.

Table 5. Results of the Analysis of the Feasibility of the Graphic Aspects

\begin{tabular}{lll}
\hline Sub Aspects & $P(\%)$ & Criteria \\
\hline Teaching material size & 91,67 & Very worthy \\
$\begin{array}{l}\text { Cover design of teaching } \\
\text { materials }\end{array}$ & 87,50 & Very worthy \\
$\begin{array}{l}\text { Design content of teaching } \\
\text { materials }\end{array}$ & 83,33 & Worthy \\
\hline
\end{tabular}

The analysis of the test results of the feasibility aspect of the graphic presented in Table 5 showed that in the aspect of graphics feasibility, the teaching materials developed to get an average percentage of $87.50 \%$ with very worthy criteria. The number was because the teaching materials used A4 paper $(21 \mathrm{~cm} \times 29.7 \mathrm{~cm})$, corresponding to ISO standards. The standard was regarded to develop physics teaching materials at school and outside of school (Prastowo, 2015). Furthermore, the cover for teaching materials developed was designed with proportional attention to the composition of the color and the size of the layout. The illustration image on the cover of teaching materials was an example of fluid application in everyday life. Pattashiki \& Hakim (2016) stated that the colors and design illustrations on the cover of attractive teaching materials could clarify the concepts, messages, and materials in teaching materials. The text in the developed teaching material is written in Times New Roman typeface and font size of 12-16 to clearly and quickly read it. As the research results, Nurhadryani et al. (2013) states that 
the appropriate type and size of letters will make it easier for students to learn the material contained in teaching materials.

\section{Readability of Teaching Materials}

Table 6 presented the results of the readability analysis of teaching materials.

Table 6. Teaching Material Readability Test Results

\begin{tabular}{lll}
\hline Grade & $P(\%)$ & Criteria \\
\hline XI MIPA 3 & 85,48 & Intelligible \\
XI MIPA 5 & 88,29 & Intelligible \\
\hline Average & 86,88 & Intelligible \\
\hline
\end{tabular}

Based on the data obtained from the readability test of teaching materials in class XI MIPA 3 and XI MIPA 5, the average percentage of teaching material readability was $86.88 \%$. These results indicated that students easily understand the teaching material. Dewi \& Arini (2018) stated that the results of a good teaching material legibility test could increase the interest in learning and the reader's memory. One of the factors supporting students' success in understanding the content of teaching materials was visual images/illustrations that support the learning material. Neina et al. (2015) stated that using photos / graphic drawings to keep learning materials can affect teaching materials' readability.

In general, the teaching materials developed to use a sentence structure following the General Guidelines for Indonesian Spelling (PUEBI). It was adapted to the reader (high school students) so that students easily understand it. The teaching materials developed were packaged in simple vocabulary to make it easier for students to understand the material. The same thing was expressed by Larasati \& Yulianti (2014) in their research which stated that teaching materials arranged using simple sentences and letters would be easier for students to understand.

\section{Student Responses to Teaching Materials}

The operational field test aimed to determine students' response to teaching materials as users regarding the display aspects of teaching materials, grammar and sentence structure, content, use, and functions of teaching materials. Also, 35 students of class XI MIPA 3 and 34 students of class XI MIPA 5 at SMA Negeri 1 Patikraja carried out assessment of students' responses to teaching materials. The choice of class XI MIPA as a respondent was due to the assumption that class XI MIPA already knew fluid material obtained in class XI in the odd semester to respond to teaching materials and questionnaires that have been compiled.

Table 7 presented the results of the student response questionnaire analysis on the display aspects of teaching materials.

Table 7. Results of Display Aspect Analysis

\begin{tabular}{lc}
\hline Sub Aspects & $P(\%)$ \\
\hline $\begin{array}{l}\text { The display of STEM teaching materials integrates 21st century skills and a } \\
\text { load of interesting characters }\end{array}$ & 87,34 \\
$\begin{array}{l}\text { The pictures contained in the teaching materials are clear and easy to } \\
\text { understand }\end{array}$ & 88,44 \\
\hline Average & 87,88 \\
\hline
\end{tabular}


Table 7 presented the display aspects. The teaching materials developed got an average percentage of $87.88 \%$ with excellent criteria in the display aspect. The rate was because the teaching materials developed could visualize the material clearly and attractively through the support of picture explanations that helped students interact to increase students' understanding (Khamidah et al., 2019). Based on students' responses in the reason/input column, it was stated that overall, the teaching materials developed have an attractive appearance and design. The images and descriptions of the ideas presented are easy to understand to motivate students to read them.

The analysis of students' questionnaire responses to teaching materials on the grammar and sentence structure aspects was based on an indicator, namely using language in teaching materials that is easy to understand. The average percentage is $88.44 \%$, with an excellent category. The rate was because the developed teaching materials present fluid material with grammar and sentence structure that has been adjusted to the General Guidelines for Indonesian Spelling (PUEBI). It also adapted to the reader's cognitive development (high school students) and has gone through material experts' validation stage. It made it easier for students to understand the fluid material in teaching materials. In line with the results of students' responses given in the reason/input column. It stated that the entire of the teaching materials developed use standard Indonesian, straightforward, and understood by students. As Rahmawati (2016) said, in the preparation of teaching materials, students must pay attention to standard, effective, and consistent sentences so that students easily understand them. Also, the choice of language in teaching materials, according to Qostantia (2017), must be adjusted to the age development of students by paying attention to sound and correct Indonesian rules.

Table 8 presented the results of the student response questionnaire analysis on the aspects of the content of teaching materials.

Regarding the analysis of the content aspects presented in Table 8, it was found that the teaching materials developed got an average percentage of $90.16 \%$ with excellent criteria in the display aspect. These results indicated that students could know the relationship between fluid material and science. They could also know various technologies that utilize the principles in a fluid material, know-how the engineering process is (designing or creating a technology) and understood aspects of mathematics as a language for science, engineering, and technology after studying fluid material the developed teaching materials. In reliance on the results of student responses given in the reason/input column, it was stated that the overall content of the material in the developed teaching materials presented material under what students have learned. The learning was in odd semesters and had many features that support the completeness of learning in class, one of which is "STEM Rubric," which contains the relationship between fluid material and aspects of science, technology, engineering, and mathematics. The multi and transdisciplinary integration of the $\mathrm{S}, \mathrm{T}, \mathrm{E}$, and $\mathrm{M}$ aspects in this teaching material can improve students' conceptual mastery (Pangesti et al., 2017).

Questionnaire students' responses to teaching materials on aspects of use were based on an indicator, namely the material in teaching materials systematically arranged and easy to understand. Based on the student response analysis results, the average percentage was $88.48 \%$, with the excellent category. The ratio was because the teaching materials developed present fluid materials packaged with STEM-based learning integrated 21st century skills (4C) and character content to give students a sustainable and robust willingness to learn (Beers, 2011; Sartika, 2019). Based on the results of students' responses given in the reason/input column, it was stated that the teaching materials developed are practically used in learning, presenting complete material about fluids, and easy to understand. As the research results of Irwandani et al. (2017) stated, material that 
is arranged systematically, logically, easily understood, and is easy to use by both educators and students has good quality and feasibility.

Table 8. Results of Content Aspect Analysis

\begin{tabular}{ll}
\hline Sub Aspects & $P(\%)$ \\
\hline $\begin{array}{l}\text { The material contained in the teaching material is following the fluid subject } \\
\text { matter }\end{array}$ & 93,14 \\
$\begin{array}{l}\text { The material contained in teaching materials relates fluid to scientific aspects } \\
\text { The material contained in teaching materials relates fluids to technological }\end{array}$ & 90,22 \\
$\begin{array}{l}\text { aspects } \\
\text { The material contained in teaching materials relates fluids to engineering }\end{array}$ & 87,34 \\
$\begin{array}{l}\text { aspects (design/engineering) } \\
\text { The material contained in teaching materials relates fluids to mathematical } \\
\text { aspects }\end{array}$ & 90,94 \\
\hline Average & 90,16 \\
\hline
\end{tabular}

Table 9 presented the results of the student response questionnaire analysis on the functional aspects of teaching materials.

Based on the analysis of the functional aspects presented in Table 9, it was found that the teaching materials developed to get an average percentage of $86.60 \%$ in the display aspect. These results indicated that the developed teaching materials function in excellent criteria. Based on the results of students' responses given in the reason/input column, it was stated that the entire of teaching materials developed are practically used in learning and are suitable if used as handbooks for students to study at school and outside of school. As the results of research by Afriana et al. (2016) states, STEM-based learning could provide a memorable experience, giving rise to motivation and interest in education.

Overall, students' responses to physics teaching materials based on STEM integrated 21 st century skills (4C) and character get reactions in the excellent category with a percentage of $88.32 \%$.

Table 9. Results of Function Aspect Analysis

\begin{tabular}{lc}
\hline Sub Aspects & $P(\%)$ \\
\hline STEM-based physics teaching materials integrated 21st century skills and & 88,07 \\
practical character content used in learning & \\
STEM-based physics teaching materials integrated with 21st century skills & 87,34 \\
and character content help you understand the subject of fluids in more depth & \\
from the aspect of science & \\
STEM-based physics teaching materials integrated with 21st century skills & 86,24 \\
and character content help you understand the subject of fluids in more depth & \\
from the technological aspects & \\
STEM-based physics teaching materials integrated with 21st century skills & 83,34 \\
and character content help you understand the subject of fluids in more depth & \\
from the engineering aspect (design/engineering) & \\
$\begin{array}{l}\text { STEM-based physics teaching materials integrated with 21st century skills } \\
\text { and character content help you understand the subject of fluids in more depth }\end{array}$ & 88,04 \\
from the aspects of mathematics & 86,60 \\
\hline Average &
\end{tabular}




\section{Interview Students' Responses to Teaching Materials}

Interviews were conducted to explore students' responses to physics teaching materials based on STEM integrated 21st century skills (4C) and character. As the opinion of Asriningtyas et al. (2018), which stated that the data of a study could be strengthened through interviews with students. In this study, the interview respondents were six students, each consisting of three students of class XI MIPA 3 and 3 students of class XI MIPA 5 SMA Negeri 1 Patikraja.

Overall, an analysis of the results of interviews with students found that STEMbased physics teaching materials integrated with 21 st century skills and character content could provide new learning experiences for students, especially concerning fluid material with science, technology, engineering, and mathematics. Students showed an interest in the teaching materials being developed. The images and language presented have helped students understand the problems presented in the teaching materials. However, there were still parts of the formula that need to be emphasized to be more visible. 21st century skills (4C), presented in the form of problems around technology related to fluids in discussion questions, have also been understood by students. Also, the presentation of character values related to the material has been understood by students. The findings from the analysis of physics teaching materials' test results based on STEM integrated 21 st century skills (4C) and character. It showed that this teaching material was practically used in learning. It could be seen from the attractive appearance, grammar, and sentence structure that is easy to understand. The content of STEM-based material integrated 21st century skills (4C) and characters that students could accept and understand their practical use. Also, the function of teaching materials that make students more interested in studying the material more deeply.

\section{CONCLUSION}

Based on the results of research conducted at SMA Negeri 1 Patikraja, several conclusions were obtained. They were that the characteristics of STEM-based physics teaching materials were integrated with 21 st century skills (4C). Also, the characters in fluid material contained the latest problems, discussion activities, practicum, and simple projects related to aspects of STEM in daily life and integrated with 21 st century (4C) skills and character. The feasibility test results based on the content, presentation, language, and graphic aspects show that the teaching materials in the category are very suitable for use in learning. The legibility test results showed the teaching materials were in the easy-to-understand type. The assessment results of students' responses to teaching materials received responses in the excellent category for use by students of class XI SMA/MA as a source of supporting teaching materials in the learning process of fluid material. Overall, the teaching materials developed provide new learning experiences from cognitive and affective aspects compared to previously used teaching materials that are only oriented to cognitive aspects.

This research suggested that further development should be needed by adding information on the $4 \mathrm{C}$ indicator in each problem presented in the teaching material. Adding experimental content using a virtual lab adds to students' learning experience independently, especially when using a distance learning system. 


\section{REFERENCES}

Afriana, J., Permanasari, A., \& Fitriani, A. (2016). Penerapan project based learning terintegrasi STEM untuk meningkatkan literasi sains siswa ditinjau dari gender. Jurnal Inovasi Pendidikan IPA, 2(2), 202. https://doi.org/10.21831/jipi.v2i2.8561

Ariyani, Y. D., \& Wangid, M. N. (2016). Pengembangan bahan ajar tematik-integratif berbasis nilai karakter peduli lingkungan dan tanggung jawab. Jurnal Pendidikan Karakter, 1. https://doi.org/10.21831/jpk.v0i1.10737

Arsyad, A. (2014). Media Pembelajaran. Jakarta: Rajawali Pers.

Asriningtyas, A. N., Kristin, F., \& Anugraheni, I. (2018). Penerapan model pembelajaran problem based learning untuk meningkatkan kemampuan berpikir kritis dan hasil belajar matematika siswa kelas 4 SD. Jurnal Karya Pendidikan Matematika, 5(1), 23-32. https://doi.org/https://doi.org/10.26714/jkpm.5.1.2018.23-32

Bappenas. (2013). Rencana Kerja Pemerintah 2013. Jakarta: Kementerian Perencanaan Pembangunan Nasional.

Beers, S. Z. (2011). 21st century skills: Preparing students for their future. Diakses dari http://cosee.umaine.edu/files/coseeos/21st_century_skills.pdf

Borg, W. R., \& Gall, M. D. (1989). Exploring relationships between variables: The causal-comparative method. Educational Research: An Introduction (5th Ed.). New York: Longman.

Budiawati, Y. S. R., \& Kantun, S. (2016). Analisis tingkat kelayakan bahan ajar ekonomi yang digunakan oleh guru di SMA Negeri 4 Jember. Jurnal Pendidikan Ekonomi, 9(2), 129-146.

Chien, P. L. K., \& Lajium, D. A. D. (2016). The effectiveness of science, technology, engineering and mathematics (STEM) learning approach among secondary school students. International Conference on Education and Psychology 2016 (ICEduPsy16), 95-104.

Choridah, D. T. (2013). Peran pembelajaran berbasis masalah untuk meningkatkan kemampuan komunikasi dan berpikir kreatif serta disposisi matematis siswa SMA. Infinity, 2(2), 194-202. https://doi.org/https://doi.org/10.22460/infinity.v2i2.p194202.

Daryanto, D., \& Dwicahyono, A. (2014). Pengembangan Perangkat Pembelajaran. Yogyakarta: Gava Media.

Depdiknas. (2008). Panduan Pengembangan Bahan Pelajaran. Jakarta: Direktorat Jenderal Manajemen Pendidikan Dasar dan Menengah.

Dewi, N. R., \& Arini, F. Y. (2018). Uji keterbacaan pada pengembangan buku ajar kalkulus berbantuan geogebra untuk meningkatkan kemampuan pemecahan masalah dan representasi matematis. Prosiding Seminar Nasional Matematika, 1, 299-303.

Fitriani, W., Bakri, F., \& Sunaryo, S. (2017). Pengembangan lembar kerja siswa (LKS) fisika untuk melatih kemampuan berpikir tingkat tinggi (high order thinking skill) siswa SMA. WaPFi (Wahana Pendidikan Fisika), 2(1), 36-42.

Herak, R., \& Lamanepa, G. H. (2019). Meningkatkan kreatifitas siswa melalui STEM dalam pembelajaran IPA. EduMatSains: Jurnal Pendidikan, Matematika dan Sains, 4(1), 89-98. https://doi.org/https://doi.org/10.33541/edumatsains.v4i1.1047

Irfana, S., Yulianti, D., \& Wiyanto, W. (2019). Pengembangan lembar kerja peserta didik berbasis science, technology, engineering, and mathematics untuk meningkatkan kemampuan berpikir kreatif peserta didik. UPEJ Unnes Physics Education Journal, 8(1), 83-89. https://doi.org/https://doi.org/10.15294/upej.v8i1.29517 
Irwandani, I., Latifah, S., Asyhari, A., Muzannur, M., \& Widayanti, W. (2017). Modul digital interaktif berbasis articulate studio'13: Pengembangan pada materi gerak melingkar kelas X. Jurnal Ilmiah Pendidikan Fisika Al-Biruni, 6(2), 221-231. https://doi.org/10.24042/jipfalbiruni.v6i2.1862

Izzati, N., Tambunan, L. R., Susanti, S., \& Siregar, N. A. R. (2019). Pengenalan pendekatan STEM sebagai inovasi pembelajaran era revolusi industri 4.0. Jurnal Anugerah, 1(2), 83-89. https://doi.org/10.31629/anugerah.v1i2.1776

Kanadli, S. (2019). A meta-summary of qualitative findings about STEM education. International Journal of Instruction, 12(1), 959-976.

Kemendikbud. (2016). Silabus Mata Pelajaran Fisika Sekolah Menengah Atas/ Madrasah Aliyah (SMA/MA). Jakarta: Kementrian Pendidikan dan Kebudayaan.

Khamidah, N., Winarto, W., \& Mustikasari, V. R. (2019). Discovery learning: Penerapan dalam pembelajaran IPA berbantuan bahan ajar digital interaktif untuk meningkatkan prestasi belajar siswa. JIPVA (Jurnal Pendidikan IPA Veteran), 3(1), 87. https://doi.org/10.31331/jipva.v3i1.770

Khusniati, M. (2012). Pendidikan karakter melalui pembelajaran IPA. Jurnal Pendidikan IPA Indonesia, 1(2), 204-210. https://doi.org/10.15294/jpii.v1i2.2140

Larasati, A., \& Yulianti, D. (2014). Pengembangan bahan ajar sains (fisika) tema alam semesta terintegrasi karakter dan berwawasan konservasi. Unnes Physics Education Journal, 3(2), 26-33. https://doi.org/https://doi.org/10.15294/upej.v3i2.3594

Neina, Q. A., Mardikantoro, H. B., \& Supriyanto, T. (2015). Pengembangan buku pengayaan menulis cerita anak bermuatan nilai karakter berdasarkan content and languange integrated learning (CLIL) untuk siswa sekolah dasar kelas tinggi. Seloka: Jurnal Pendidikan Bahasa dan Sastra Indonesia, 4(2), 50-57. https://doi.org/https://doi.org/10.15294/seloka.v4i2.9860

Nurgiyantoro, B., \& Efendi, A. (2013). Prioritas penentuan nilai pendidikan karakter dalam pembelajaran sastra remaja. Jurnal Cakrawala Pendidikan, 32(3), 382-393. https://doi.org/10.21831/cp.v3i3.1626

Nurhadryani, Y., Sianturi, S. K., Hermadi, I., \& Khotimah, H. (2013). Pengujian usability untuk meningkatkan antarmuka aplikasi mobile. Jurnal Ilmu Komputer dan AgriInformatika, 2(2), 83-93. https://doi.org/10.29244/jika.2.2.83-93

Oktaviani, W., Gunawan, G., \& Sutrio, S. (2017). Pengembangan bahan ajar fisika kontekstual untuk meningkatkan penguasaan konsep siswa. Jurnal Pendidikan Fisika Dan Teknologi, 3(1), 1-7. https://doi.org/10.29303/jpft.v3i1.320

Pala, A. (2011). The need for character education. International Journal of Social Sciences and Humanity Studies, 3(2), 23-32.

Pangesti, K. I., Yulianti, D., \& Sugianto, S. (2017). Bahan ajar berbasis STEM (science, technology, engineering, and mathematics) untuk meningkatkan penguasaan konsep siswa SMA. UPEJ Unnes Physics Education Journal, 6(3), 53-58. https://doi.org/https://doi.org/10.15294/upej.v6i3.19270

Parmin \& Peniati, E. (2012). Pengembangan modul mata kuliah strategi belajar mengajar IPA berbasis hasil penelitian pembelajaran. Jurnal Pendidikan IPA Indonesia, 1(1), 8-15. https://doi.org/https://doi.org/10.15294/jpii.v1i1.2006

Pattashiki, V. (2016). Pengembangan lembar kegiatan siswa dalam menunjang kegiatan belajar di kurikulum 2013 materi jurnal khusus. Jurnal Pendidikan Akuntansi (JPAK), 4(3), 1-5.

Prastowo, A. (2015). Panduan Kreatif Membuat Bahan Ajar Inovatif. Yogyakarta: Diva Press.

Purnanto, A. W., \& Mustadi, A. (2018). Analisis kelayakan bahasa dalam buku teks tema 1 kelas i sekolah dasar kurikulum 2013. Profesi Pendidikan Dasar, 3(2), 102-111. https://doi.org/10.23917/ppd.v3i2.2773 
Qostantia, L. N. (2017). Bahan Ajar Menulis Cerita Fabel dengan Stimulus Film Finding Nemo. Jurnal Pendidikan: Teori, Penelitian, Dan Pengembangan, 2(3), 377-384. https://doi.org/http://dx.doi.org/10.17977/jptpp.v2i3.8635

Rahmawati, I. S., Roekhan, R., \& Nurchasanah, N. (2016). Pengembangan media pembelajaran menulis teks fabel dengan macromedia flash bagi siswa SMP. Jurnal Pendidikan: Teori, Penelitian, dan Pengembangan, 1(7), 1323-1329. https://doi.org/http://dx.doi.org/10.17977/jp.v1i7.6561

Rahmayantis, M. D. (2017). Pengembangan Bahan Ajar Membaca Indah Puisi untuk Siswa SMP Kelas VII. KEMBARA: Jurnal Keilmuan Bahasa, Sastra, Dan Pengajarannya, 2(1), $47-56$. https://doi.org/https://doi.org/10.22219/kembara.v2i1.4043

Saputra, M. D., Joyoatmojo, S., Wardani, D. K., \& Sangka, K. B. (2019). Developing critical-thinking skills through the collaboration of jigsaw model with problembased learning model. International Journal of Instruction, 12(1), 1077-1094.

Sarı, U., Alıc1, M., \& Şen, Ö. F. (2018). The effect of STEM instruction on attitude, career perception and career interest in a problem-based learning environment and student opinions. The Electronic Journal for Research in Science \& Mathematics Education, 22(1), 1-21.

Sartika, D. (2019). Pentingnya pendidikan berbasis STEM dalam kurikulum 2013. JISIP (Jurnal Ilmu Sosial dan Pendidikan), 3(3), 89-93. https://doi.org/http://dx.doi.org/10.36312/jisip.v3i3.797

Scott, C. L. (2015). The Futures of Learning 3: What kind of pedagogies for the 21st century? Paris: UNESCO.

Situmorang, M. (2014). Pengembangan buku ajar kimia SMA melalui inovasi pembelajaran dan integrasi pendidikan karakter untuk meningkatkan hasil belajar siswa. Prosiding SEMIRATA 2013, 1(1).

Sorraya, A. (2014). Pengembangan bahan ajar teks prosedur kompleks dalam pembelajaran Bahasa Indonesia untuk kelas X SMK. NOSI, 2(2), 13-28.

Wahyuni, A. I., Astuti, B., \& Yulianti, D. (2017). Bahan ajar fisika berbasis I-SETS (islamic, science, environment, technology, society) terintegrasi karakter. UPEJ Unnes Physics Education Journal, 6(3), 17-25. https://doi.org/10.15294/upej.v6i3.19309

Widayoko, A., Latifah, E., \& Yuliati, L. (2018). Peningkatan kompetensi literasi saintifik siswa SMA dengan bahan ajar terintegrasi STEM pada materi impuls dan momentum. Jurnal Pendidikan: Teori, Penelitian, dan Pengembangan, 3(11), 1463-1467. https://doi.org/10.17977/jptpp.v3i11.11767

Yildirim, B. (2016). An analyses and meta-synthesis of research on STEM education. Journal of Education and Practice, 7(34), 23-33.

Yıldırım, B., \& Altun, Y. (2015). STEM eğitim ve mühendislik uygulamalarının fen bilgisi laboratuar dersindeki etkilerinin incelenmesi. El-Cezeri Journal of Science and Engineering, 2(2), 28-40. https://doi.org/10.31202/ecjse.67132 